\title{
NON-REPRESENTATIONAL LANGUAGE IN MIPAM'S RE-PRESENTATION OF OTHER-EMPTINESS
}

\section{Douglas S. Duckworth}

Temple University

douglas.duckworth@temple.edu

\section{Introduction}

Buddhist traditions understand emptiness in various ways, and two streams of interpretation, "self-emptiness" (rang stong) and "other-emptiness" (gzhan stong), have emerged in Tibet that help bring into focus the extent to which interpretations diverge. ${ }^{1}$ In contrast to self-emptiness, other-emptiness does not refer to a phenomenon's lack of its own essence; it refers to the ultimate reality's lack of all that it is not. Rather than claiming the universality of self-emptiness (emptiness as lack of own essence), proponents of other-emptiness assert another way to understand emptiness with regard to the ultimate (emptiness as ultimate ground). These two interpretations of emptiness - as ground and as groundless abyss — reveal a rift at the foundation of Buddhist metaphysics.

This essay probes the discourses of other-emptiness in the Jonang (jo nang) and Nyingma (rnying ma) traditions. After briefly introducing other-emptiness in the Jonang tradition, the locus classicus for other-emptiness in Tibet, I will contrast the way Mipam ('ju mi pham rgya mtsho) (1846-1912) positions the discourse of other-emptiness in his interpretative system. I will then demonstrate how Mipam's portrayal of other-emptiness highlights the way he uses a perspectival means to incorporate a diversity of seemingly contradictory claims that he uses to support his view of ultimate reality as indeterminate. I will argue that an implication of his view is a non-representational account of language about the ultimate.

\section{The Ground of the Jonang and Nyingma}

Dölpopa (dol po pa shes rab rgyal mtshan) (1292-1361) is famous for promoting the view of "other-emptiness" by portraying the ultimate ground of reality as not empty of its own essence. He represents this ultimate ground as the omnipresent reality that is only "empty" in the sense that it is empty of all the distorted, relative phenomena extrinsic to it. Dölpopa privileges the ultimate truth as the real truth and rejects the reality of the relative truth, which he claims to be utterly unreal, like "the horns of a rabbit." 2

Dölpopa thus emphasizes a radical separation between two distinct worlds-the relative and the ultimate-in his characterization of the two truths: what is ultimate is necessarily not what is relative and vice versa. Reflecting the separation between 
the relative and ultimate, he makes a distinction between the universal ground consciousness (kun gzhi'i rnam shes) and the universal ground wisdom (kun gzhi'i ye shes). ${ }^{3}$ This "universal ground wisdom" is a distinctive term in the Jonang tradition that is not used in the prominent Nyingma works I discuss below. ${ }^{4}$ This terminology reflects how Dölpopa preserves a form of dualism in his explanations-a radical dichotomy of an ultimately (1) nonexistent relative and (2) existent ultimate.

Such a dichotomy is unlike the strong monism we often find in Mipam's portrayals of a Nyingma view, where the ultimate and relative are ultimately non-distinct, and saṃsāra and nirvāṇa have a common ground. Mipam's emphasis on unity (zung 'jug) distinguishes his works from Dölpopa's representations of reality, which privilege the ultimate truth. In light of this, it is not surprising that Mipam does not separate a universal ground wisdom from a universal ground consciousness, but simply states that "the basic reality (chos nyid) of consciousness is wisdom" (rnam shes kyi chos nyid ye shes so). ${ }^{5}$ While he may concede that consciousness (or the conceptual mind) is the basis of samsāra, whereas wisdom is the basis of nirvāṇa, Mipam conveys the relationship between wisdom (ye shes) and mind (sems) as a unity, akin to the relationship between emptiness and the mind. He says:

One should understand that wisdom does not arise from mind, but is the abiding reality of mind, which is naturally luminous and clear; in the way that emptiness - the basic reality of all entities-does not arise from entities, but is the abiding reality of entities. ${ }^{6}$

Thus, rather than a dichotomous relationship between two separate grounds of the ultimate and relative, as is the emphasis of Dölpopa's portrayal of other-emptiness, we can say that Mipam maintains a dialectical relationship between the two truths, a dialectical unity. As such, the ultimate and the relative have a common ground; they are only virtually distinct, but not actually so. Thus, unity, for Mipam, is the consummate meaning of the ultimate. ${ }^{7}$

This unity undermines a privileged status for ultimate reality, which is the reason why Mipam does not in the end assert a metaphysical dualism of two truths that privileges the ultimate. For instance, Mipam claims that mind and wisdom are conventionally not the same, but ultimately are not different. He says that consciousness and wisdom are not the same conventionally because they are related as phenomena (chos) and basic reality (chos nyid); yet, ultimately they are not different because the nature of mind is wisdom. ${ }^{8}$ Significantly, he illustrates that a unique feature of the path of the Great Perfection (rdzogs chen) is that wisdom, "the primordial luminous clarity" (gdod ma'i 'od gsal) can be recognized while the objects of the eight consciousnesses have not ceased. ${ }^{9}$ This wisdom is thus not some separate state or transcendent experience divorced from typical conscious states and processes of the world. Rather, his words suggest a common ground of consciousness and wisdom. He states:

When the nature of this ground is realized, one is liberated, when it is not, one is confused. Due to this, both buddhas and sentient beings come to be. Thus, it is said, "There is one ground and two paths." 10 
A precursor to this single ground that supports both wisdom and consciousness, buddhas and sentient beings, can be found in the works of Mipam's Nyingma predecessor, Longchenpa (klong chen rab 'byams) (1308-1364), in his characterization of a "general ground" (spyi gzhi) as the ground of both samsāra and nirvāna.."

While I want to point out how unity plays a role in this Nyingma tradition to elude a metaphysical bifurcation of two realities, the difference between the Jonang and the Nyingma should not be misunderstood as a simple difference between dualism and monism. This is because there is a context for the distinction between mind (sems) and awareness (rig pa) in the Nyingma tradition's Great Perfection that is similar to the distinction between consciousness (rnam shes) and wisdom (ye shes) in the Jonang tradition's other-emptiness. Also, the two traditions can be seen respectively to relate to different contexts (i.e., meditative equipoise and postmeditation), in which the Great Perfection texts that collapse the distinction between the relative and ultimate can be seen to evoke the ultimate as a phenomenological awareness known in meditative experience, and the Jonang discourses of other-emptiness that make a sharp distinction between the relative and ultimate can be seen to describe this ultimate (or authentic experience) as it is theorized in postmeditation. The distinction between these traditions is thus not necessarily so clear cut.

So what does Mipam's position on the ground-whether it is formulated as one or two (a ground of consciousness and a ground of wisdom) - tell us about his view of other-emptiness? And how does he reconcile a claim about the ground with the Madhyamaka view that there is no ground-in the sense of a ground that is a substance or foundation - for we do not need to look hard to find other authoritative texts in this tradition where any and all grounds are denied? I want to argue that we can find an interesting philosophical answer (or, rather, philosophical avenue) through looking further into the matter of perspectivalism. In the next section, I will argue that Mipam's perspectival approach allows him to incorporate the discourses of other-emptiness alongside several competing descriptions of ultimate truth. I will argue that his endorsement of pluralistic and conflicting representations of the ultimate shows that he does not treat language about the ultimate as representational. This is an upshot of his view that ultimate reality is indeterminate.

\section{Other-Emptiness in Perspective}

When reading Mipam, it is important to appreciate his perspectival approach to Buddhist hermeneutics, and see how different statements resonate within the contexts of different perspectives and functions. Through this, we can see how language need not always carry one-dimensional, universally applicable, "one-size-fits-all" meanings. For instance, if we come across authoritative Buddhist texts that affirm that there is one ground, claim that there are two grounds, or deny any and all grounds, they can all convey truth despite being contradictory. This is the case not only when these statements are taken in light of a particular context—such as when they are qualified by certain modifiers (such as, conventionally it is like this ...., but ultimately it is not. . . .) - but, rather, when these words are not taken to represent reality. 
Here we should bear in mind that statements about a "ground" (gzhi) are metaphorical; conflicting statements can be reconciled when they are seen to function as metaphors rather than seen as representing facts about a real world out there. In other words, it is important to keep in mind that metaphors are linguistic media, and like works of art they can open up worlds through evoking meaning. In a significant way, metaphors do not simply re-present; they dis-close. They not only work within the closures of preconceived notions; they also function to disrupt and transcend them. In this light, the language (about emptiness and about the ground) can function to evoke and awaken awareness, and thus transform our way of being in the world. The important point here is this: the meaning of language need not be objectoriented. Rather, the sense of words like "ground" and "emptiness" can lack objective referents, yet point to a participatory encounter, in a way similar to what Paul Riceour has suggested by the "non-ostensive reference" or "depth semantics" of a text. ${ }^{12}$ In such a case, their meanings are found in modes of subjectivity or interactions rather than being hooked up to static referents or essences "out there."

In this light, we can see how there can be multiple, conflicting descriptions of the ground or emptiness in Buddhist texts that can all be true, not simply because there are different beings, and thus different ways of relating to words and worlds, but because the ultimate sense of the "ground" is not referring to something out there in the world. Given that he maintains that the ground is groundless or that emptiness is empty, Mipam's interpretation does not rigidly hold on to the reality of any particular Buddhist claim as the accurate representation. This allows him to voice multiple views (and thus harmonize different positions) without binding him to a singular ontological position (and thus affirm the indeterminacy of the ultimate-a hallmark of his Nyingma tradition's view of the Great Perfection). A singular representation that claims to be the sole accurate representation of the ultimate (such as the Brahman of Vedānta or a full embrace of a determinate emptiness [qua absence] as in Tsongkhapa's Prāsanigika-Madhyamaka exclusivism) is antithetical to his position regarding the indeterminacy of the ultimate.

Since language is always contingent upon the particular context at hand, contradicting ways of expressing the ultimate need not always compete, and furthermore are even necessary when they serve distinct communicative functions (to represent or evoke) the ultimate. ${ }^{13}$ For Buddhists like Mipam, direct knowledge of the ultimate is nonconceptual, but this knowledge will be evoked and theorized in different ways given the context. Mipam's flexibility in entertaining multiple registers of meaning for emptiness and ground can be understood through acknowledging the indeterminacy of the ultimate that his perspectivalism affords.

Bötrül (bod sprul mdo sngags bstan pa'i nyi ma) (1898-1959), an important commentator on Mipam's writings, has offered a particularly valuable way to interpret conflicting descriptions of emptiness through which he incorporates the discourses of other-emptiness into a Nyingma view. To give an example of this, he describes a Nyingma representation of the Madhyamaka view as "self-emptiness" in contrast to a Geluk (dge lugs) claim of "emptiness of true existence" (bden stong) and a Jonang claim of "other-emptiness," yet he does so in a way that allows these claims all to 
represent the truth, within a particular framework. He makes the distinction between the three traditions based on the different ways the object of negation can be identified in Madhyamaka. ${ }^{14}$

Bötrül states that the primary object of negation for traditions professing "otheremptiness" (e.g., the Jonang tradition) is inauthentic or distorted experience, the primary object of negation for the Svātantrika (a.k.a. the Geluk tradition) is true existence, and the primary object of negation for traditions professing "self-emptiness" (or Prāsangika) is any conceptual reference. Accordingly, he says that the relationship between the two truths in Madhyamaka also can be expressed in three ways (depending on context). (1) In the context of professing other-emptiness, the two truths are said to be different in the sense of "negating that they are one" (gcig pa bkag pa), which expresses an appearance-reality distinction between what is ontologically real and what is not (yet is apparent and deceptive). (2) In the contexts of Svātantrika discourse, they are said to be "the same with different contradistinctions" (ngo bo gcig la Idog pa tha dad), which expresses a conceptual distinction between what is essentially the same (like something that is impermanent and a product). (3) In Prāsanigika discourse, the two truths are "neither one nor many" (gcig du bral), which expresses the (non-)relation of nonduality (that defies any assertion of relation). ${ }^{15}$ In this way, he outlines three different approaches to Madhyamaka. Yet none of these presentations are exclusively right and none are absolutely wrong, for they are all different ways of representing truth from different perspectives.

By this, Bötrül expresses the theme of unity in his exegesis of Mipam's Nyingma view by not taking a position per se but by relating to language as language, and appropriating all these articulations of Madhyamaka within a particular context of use, and thus harmonizing them all.

In this way, he does not, for instance, take an either/or position on dichotomies such as: (1) emptiness in the middle wheel of sūtra versus buddha-nature in the last wheel of sūtra, or (2) Prāsanigika-Madhyamaka versus the "Great Middle Way" of other-emptiness. Rather, he integrates the two sides of these dichotomies into a tradition that he calls the "Great Prāsanigika" (thal 'gyur chen po). This is a (non)sectarian position that does not privilege the claim of "other-emptiness" as the culmination of all views, but rather incorporates it-alongside aspects of Tsongkhapa's (tsong kha pa blo bzang grags pa) (1357-1419) Prāsanigika, which denies any real grounds-as simply another description of Madhyamaka.

A key to this integration is the indeterminacy of the ultimate, and "unity," which is illustrated in the Prāsangika's perspective on nonduality. In contrast, the Jonang and Geluk positions represent a structure of metaphysical dualism. That is, the Jonang tradition's dualism takes the ultimate truth to be ultimately real while the conventional truth is not, whereas the structure of the Geluk tradition is also dualistic in that the conventional truth is real while the ultimate truth is not. In other words, the substrate of the Jonang position is the ultimate ground (deceptively qualified by empty, relative phenomena) whereas the substrate(s) of the Geluk position are the relative phenomena, which are qualified by ultimate emptiness. In contrast, the $\mathrm{Ny}$ - 
ingma tradition's "Great Prāsañgika" undermines the dualism of an ultimate/relative metaphysical divide with the indeterminate unity of appearance and emptiness (appearing emptiness), while allowing these alternative representations to (also) voice truth within a provisional context.

Although the Geluk tradition's representation of the ultimate, which asserts no ultimate truth (or rather, that the ultimate truth means precisely an absence of essence), is quite different from the Jonang tradition's assertion of an ultimate ground of reality, I want to point out a similarity between the Jonang and Geluk traditions here: they both can be seen to represent the determinacy of ultimate reality in their discourses. That is, they both primarily seek to determine ultimate reality by affirming what it is (especially in the Jonang tradition) and by clearly demarcating the boundaries of what it is not (especially in the Geluk tradition). While Mipam does this, too, he is primarily concerned with undermining language's ability to represent ultimate truth (even by negation), so his indeterminate ultimate of unity contrasts with the dualism that structures the singularly determinate representations of the ultimate in both the Geluk and the Jonang traditions. A consequence of determinate representation of ultimate truth is a bifurcation of reality. As a champion of indeterminacy, Mipam is able to avoid this metaphysical commitment in the end. Also, with his perspectival approach, he is able to bring otherwise conflicting descriptions of the ultimate (as absence and as ground) into his system.

\section{The Referent of Negations Is a Negation of Referents}

Due in part to this inclusivity, there has been a lot of debate among traditional Tibetan and academic scholars about what position Mipam is committed to. Mipam himself raised the following question in his Beacon of Certainty: How is emptiness understood in the Nyingma tradition, as an implicative negation (ma yin dgag, paryudāsapratiședha) or a non-implicative negation (med dgag, prasajya-pratiședha)? ${ }^{16}$ That is, should emptiness be understood to (literally) imply nothing, or does emptiness (metaphorically) imply something? In Tibetan thought, an implicative negation is an explicit negation that implies something else in contrast to a non-implicative negation, which is a simple negation. While a number of meanings can be ascribed to "selfemptiness" and "other-emptiness," preference for an implicative negation versus a non-implicative negation when indicating the ultimate truth is one of the main ways in which the positions are delineated. ${ }^{17}$ There is much debate among Tibetan scholars on this issue, and even debate about where Mipam comes down on this. Does his position entail his endorsement of one position or the other? That is, does he really insist on emptiness being (explicitly) defined as a non-implicative negation, or is he in the end (implicitly) advocating an emptiness that is an implicative negation?

Depending on how self-emptiness and other-emptiness are defined, Mipam can be called a proponent of both (or neither). He aligns himself as a proponent of "selfemptiness" because he does not assert that anything ultimately exists. ${ }^{18}$ When we consider the way he depicts the ultimate truth as nonconceptual wisdom, however, 
we could say that the "non-" (mi) in his portrayal of the nonconceptual (mi rtog pa) is an implicative negation because the word "nonconceptual" implies that there must still be some sort of experience happening, otherwise that experience would be hollow and lifeless, which he denies. Alternatively, we could say that the non- in nonconceptual is better understood as a non-implicative negation because its true meaning involves no word or thought and so is best reflected as an utter negation of thought that implies nothing. Mipam's words also suggest this. Taking one or the other of these stances on the import of Mipam's works, many contemporary scholars, Western Buddhists and Tibetan academics alike, disagree as to how to interpret Mipam's view. ${ }^{19}$

Mipam clearly says that a statement of emptiness (as a lack of true existence) should be understood to be a non-implicative negation, not an implicative negation. He says so because an implicative negation in the end just involves another entity conceptualized in the mind. ${ }^{20}$ It would seem, then, that the case is closed. However, a negative statement indicating emptiness is nothing more than words of language. But what about emptiness as it is experienced in meditation? Is that an implicative or a non-implicative negation? Again, we have recourse to Mipam's own words: he says that in the perspective of wisdom, the view is neither an implicative negation nor a non-implicative negation. ${ }^{21}$ Here we are left with a puzzle. In terms of how emptiness is experienced, the nonconceptual "content" of emptiness need not be evoked by a negation exclusively; given that it is nonconceptual, there is no reason why it could not be evoked by an affirmation as well. Since the view in meditative equipoise is beyond affirmation and negation, it is also beyond both implicative and nonimplicative negations, and any other linguistic or conceptual formulation.

We can see, depending on the purpose at hand and the intended context, how a case can be made for nonconceptual "content" to be represented by an implicative negation or a non-implicative negation. Yet we should also recognize that neither implicative nor non-implicative negations can represent emptiness in the perspective of wisdom beyond concepts (after all, it is inexpressible), and insisting that the content of nonconceptual experience be determined would undermine the possibility of its meaning from being understood. Nevertheless, we can also see how each of the two types of negations can, depending on context, play a role in overcoming a tendency toward reification: a non-implicative negation can function to overcome the tendency to pin down the nonconceptual, or frame it as some sort of idea, while an implicative negation can function to overcome the tendency to hold onto it as a simple absence by calling us to follow after the negation to an unthematized cognitive presence. Even so, neither form of negation can adequately represent the meaning of what is nonconceptual, because (to state the obvious) as soon as it is determined by a thought or singularly defined by language, necessarily it will not adequately reflect that experience because of being a mere conceptualization of it.

Making sense of what is at stake in the debates in Tibet between self-emptiness and other-emptiness calls for attention to the importance of perspectives, or contexts, 
with regard to discourse relating to ultimate truth and the experience of it. In the context of meditative equipoise directly experiencing the ultimate truth, the fact that there are no concepts is not debated by Tibetan Buddhists. Nevertheless, when this experience is theorized in postmeditation, we come across different accounts of this experience, and disagreements as to how it should be represented or evoked in the best way. In the contexts of theorizing this experience, we are confronted with the problem of how to conceptualize the nonconceptual and express the inexpressible. This issue is at the heart of the self-emptiness versus other-emptiness debate.

\section{Conclusion}

We have seen how Mipam's portrayal of the ground differs from the way the ground is described in Dölpopa's Jonang tradition. The ultimate in the Jonang tradition of other-emptiness is represented as not empty of its own essence, but empty of all distorted, relative phenomena. Consequently, in the Jonang tradition, the ultimate and relative are represented as distinct, as are the universal ground wisdom and consciousness. In contrast to this dichotomy of truths, Mipam emphasizes the unity of samsāara and nirvāna, and the unity of the relative and ultimate. This unity is indeterminate. With this unity, he avoids the metaphysical claims that represent a determinate, ultimately existing reality within the framework of a dichotomous structure of truth.

Yet Mipam is flexible enough to co-opt the discourses of other-emptiness to support his view, without the same kind of ontological commitments. He can do so, as I have argued, because of his perspectivalism, and specifically because he does not treat language as representing ultimate facts about a world out there. For Mipam, emptiness does not simply mean a phenomenon's lack of true essence, as it can mean in a Geluk tradition, and neither does it simply mean nirvāṇa's lack of saṃsāra, as it can mean in a Jonang tradition's other-emptiness. While he is willing to incorporate these competing claims about emptiness in a particular context, for him the ultimate sense of emptiness is an indeterminate unity. Unlike the notions of emptiness that have a singular, one-dimensional referent, Mipam highlights the way that the ultimate sense of emptiness can be neither directly referred to nor represented. He highlights its indeterminate quality and its meaning of unity, which is inclusive of awareness.

Thus, we can understand why he speaks of the ultimate in what I have referred to as metaphorical in contrast to ontological language. ${ }^{22}$ His approach to language underscores how the meaning of these words about ultimate reality-terms such as "emptiness" and "ground" — for him are to be found, or rather dis-covered, in what is inclusive of awareness rather than in independent entities. In any case, there need be no contradiction in conflicting statements that there is one ground, two grounds, or no ground, because the meanings of these statements are determined by their functions - their evocative or descriptive power in a given context-and not by how accurately they correspond to an objective referent outside the mind. 
1 - In this article I use the THL Simplified Phonetic Transcription of Standard Tibetan, developed by David Germano and Nicolas Tournadre, to transcribe Tibetan words into English.

2 - Dölpopa, The Mountain Doctrine: Ocean of Definitive Meaning, 483.7-484.1.

3 - Dölpopa, The Categories of the Possible and the Impossible, 314.2. See also Stearns, The Buddha From Dolpo, pp. 51-52.

4 - While Longchenpa (klong chen rab 'byams) (1308-1364) did not use the term "universal ground wisdom," others in the Nyingma tradition, such as Getsé Paṇchen (dge rtse pạ̣ chen, 'gyur med tshe dbang mchog grub) (1761-1829), drew upon a language of "other-emptiness" that is characteristic of the Jonang tradition. See Duckworth, Mipam on Buddha-Nature, pp. 50-51.

5 - Mipam, Intelligent Presence, 446.5-446.6.

6 - Mipam, Vajra Essence, 372.3-372.4:

ye shes ni sems las byung ba ma yin te/ sems kyi gnas lugs rang bzhin 'od gsal yin pas/ dngos po kun gyi chos nyid stong pa nyid ni dngos po'i gnas lugs yin gyi dngos po las byung ba min pa Itar go dgos.

7 - See Duckworth, Mipam on Buddha-Nature, p. 91.

8 - Mipam, Intelligent Presence, 447.2-448.1:

des na rnam shes tshogs brgyad chos can dang/ de'i rang bzhin chos nyid kyi ye shes gnyis ni/ gcig tha dad gang du'ang khas blangs bya min par. ... de gnyis tha snyad du gcig ma yin te/sems rtogs pa tsam gyis sems kyi chos nyid ye shes mi rtogs pa dang/chos dang chos nyid yin pa sogs kyi phyir ro/don dam par tha dad min te/ sems kyi rang bzhin ye shes yin pas/ ye shes rtogs dus sems kyang de las tha dad du ma dmigs pa'i phyir dang/ ye shes rtogs tshe sems rang grol du 'char ba.

The two, (1) phenomena, which are the eight collections of consciousness, and (2) the wisdom that is the basic reality, which is the nature of those [consciousnesses], are not asserted as either the same or different. ... [C]onventionally, the two are not the same because (1) wisdom, the basic reality of mind, is not realized by merely realizing the mind and (2) [mind and wisdom] are phenomena and basic reality. Ultimately, they are not different because, due to the nature of mind being wisdom, (1) when wisdom is realized, the mind is also not observed as different from that [wisdom], and (2) when wisdom is realized, the mind arises as self-liberated.

See also Mipam, Lion's Roar: Exposition of Buddha-Nature, 585.1-585.2; English translation in Duckworth, Mipam on Buddha-Nature, pp. 163-164.

9 - See Mipam, Precious Vajra Garland, 659.5-659.6.

10 - lbid., 702.

11 - Yet in a way similar to Dölpopa, Longchenpa also makes a consciousness/ wisdom distinction, in addition to making a distinction between the universal 
ground (ālaya, kun gzhi) and the dharmakāya (chos sku). For Longchenpa's distinction between the universal ground and the dharmakāya/wisdom, see, for instance, Longchenpa, Precious Treasury of the Expanse of Phenomena, 500.2506.1, Precious Treasury of Words and Meanings, 929.5-935.4, and Precious Treasury of the Supreme Vehicle, vol. 1, 1020.1-1027.3.

12 - See Paul Ricoeur, Interpretation Theory, p. 87.

13 - Jorge Ferrer presents an extremely thought-provoking argument on the compatibility of competing claims to ultimate truth in his article, "Spiritual Knowing as Participatory Enaction."

14 - See Bötrül, Distinguishing the Views and Philosophies, 37; English translation by Duckworth in Bötrül, Distinguishing the Views and Philosophies: Illuminating Emptiness in a Twentieth-Century Tibetan Buddhist Classic, pp. 57-58.

15 - Bötrül, Ornament of Mañjughoșa's Viewpoint, pp. 129-130; English translation in Bötrül, Distinguishing the Views and Philosophies: Illuminating Emptiness in a Twentieth-Century Tibetan Buddhist Classic, pp. 149-150.

16 - Mipam, Beacon of Certainty, 5:

dge Idan Ita ba med dgag zer//gzhan rnams ma yin dgag tu smra/ /snga 'gyur ring lugs gang zhes na/ /stong tshul kho na bsam nas ni//dri na med dgag nyid yin te/ /'phags yul dpal Idan zla ba dang//bod na rong zom chos bzang gnyis//dgongs pa gcig dang dbyangs gcig gis/ /ka dag stong pa chen po bsgrubs.

It is said that the Geluk (dge Idan) view is a non-implicative negation; other traditions speak of an implicative negation-if one asks, "Which is the tradition of the early translations [of Nyingma]?" Considering only the manner of emptiness, when questioned [what is the Nyingma view], it is only a non-implicative negation. The glorious Candrakirti in the Noble Land [of India] and Rongzom Chözang in Tibet established with one viewpoint and one voice the great emptiness of primordial purity.

17 - See Duckworth, Mipam on Buddha-Nature, pp. 61-62, 66; 72-74.

18 - Mipam, Difficult Points of Scriptures in General, p. 450:

rang stong pa'i lugs la don dam par med pa sha stag pas/don dam par yod pa'i chos mi srid la/gzhan stong pa'i lugs la/don dam par med na kun rdzob dang/don dam par yod la don dam rang nyid yin pa'i phyir ro/ rang lugs rab lan du gsal te rang stong smra ba'i lugs so.

In the tradition of self-emptiness, since there is only the ultimately nonexistent, an ultimately existing phenomenon is impossible. In the tradition of other-emptiness, what is ultimately nonexistent is the relative, and what is ultimately existent is the ultimate itself. My tradition is clear in the Rapsel Rejoinder, the tradition propounding selfemptiness.

See also Duckworth, Mipam on Buddha-Nature, pp. 74-75.

19 - See, for instance, Karma Phuntso, Mipam's Dialectics and the Debates on Emptiness, p. 16. 
20 - Mipam, Commentary on the Wisdom Chapter, 10:

stong pa nyid ston pa'i skabs su gzugs la sogs pa dgag pa ni med dgag kho na yin te/ ma yin par bkag kyang mthar gtugs na dngos por zhen pas stong nyid kyi don du mi rung bas med par dgag pa yin bzhin du/rten 'byung bslu med du snang bas snang stong zung du 'jug pas na dgag sgrub kyi 'dzin stangs zhig gzhig dgos te.

In the context of indicating emptiness, the negation of form, etc. is only a non-implicative negation. Since an implicative negation is also in the end a fixation upon an entity, it is not suitable to be the meaning of emptiness. Therefore, while it is a non-implicative negation, due to appearing as an unfailing interdependent arising, it is the unity of emptiness and appearance, so any apprehension of negation or affirmation should deconstruct.

See also Duckworth, Mipam on Buddha-Nature, p. 87.

21 - Mipam, Beacon of Certainty, p. 5:

zung 'jug ye shes chen po'i ngor//med ces dgag bya bkag shul gyi//med rkyang dang ni ma yin zhes/ /bkag shul chos gzhan ci zhig 'phen/ de gnyis blo yis brtag pa tsam//don la gnyis kar khas mi len.

From the perspective of the great wisdom of unity, the elimination of the object of negation by "non-existent" implies neither a mere existential absence nor a predicative negation-what other phenomenon is there to imply by negation? Both of these are merely mental imputations. I assert neither as the [consummate] meaning.

And again from the Beacon of Certainty, p. 49:

sems 'das ye shes yin pa'i phyir//rtog pa gzhan gyis bsam mi khyab//de ni sgra rtog yul min phyir/ /med dgag ma yin dgag sogs dang//tha dad dang ni snang stong sogs//ris su chad pa med pa ste.

Since wisdom transcends the mind, it is inconceivable by an extrinsic thought. Since it is not an object of language or thought, there is no partiality for non-implicative negations or implicative negations, difference, appearance or emptiness, etc.

See also Duckworth, Mipam on Buddha-Nature, pp. 86-87.

22 - By "ontological" I specifically mean the concern with discrete essences and entities, not ontological in distinction to ontic in Heidegger's redressed "ontological difference," where we may find some interesting points of comparison here with Mipam.

\section{References}

Bötrül (bod sprul mdo sngags bstan pa'i nyi ma) (1898-1959). Collected Works (bod sprul mdo sngags bstan pa'i nyi ma'i gsung 'bum). 3 vols. Sichuan: Nationalities Press, 2004.

Distinguishing the Views and Philosophies: A Lamp of Essential Points (Ita grub shan 'byed gnad kyi sgron me). In Bötrül, Collected Works, vol. 1, pp. 1-51. 
. Distinguishing the Views and Philosophies: Illuminating Emptiness in a Twentieth-Century Tibetan Buddhist Classic. Translated, annotated, and introduced by Douglas Duckworth. Albany: State University of New York Press, 2011.

- Ornament of Mañjughoșa's Viewpoint: An Explanation of the Words and Meanings of "Distinguishing the Views and Philosophies: A Lamp of Essential Points" (Ita grub shan 'byed gnad kyi sgron me'i tshig don rnam bshad 'jam dbyangs dgongs rgyan). In Bötrül, Collected Works, vol. 1, pp. 53-259.

Dölpopa (dol po pa shes rab rgyal mtshan) (1292-1361). The Categories of the Possible and the Impossible (srid mi srid kyi rab dbye dbu phyogs legs par bzhugs so). In Collected Works, 'dzam thang ed., vol. 6, pp. 305-316.

- The Mountain Doctrine: Ocean of Definitive Meaning (ri chos nges don rgya mtsho). Gangtok: Dodrup Sangyey Lama, 1976.

Duckworth, Douglas. Mipam on Buddha-Nature. Albany: State University of New York Press, 2008.

Ferrer, Jorge. "Spiritual Knowing as Participatory Enaction." In The Participatory Turn: Spirituality, Mysticism, Religious Studies, edited by Jorge Ferrer and Jacob Sherman, pp. 135-169. Albany: State University of New York Press, 2008.

Longchenpa (klong chen rab 'byams) (1308-1364). Seven Treasuries (mdzod bdun). 7 vols. Edited by Tarthang Tulku. Included within this work are the following:

- Precious Treasury of Philosophies (theg pa mtha' dag gi don gsal bar byed pa grub mtha' rin po che'i mdzod).

- Precious Treasury of the Expanse of Phenomena (chos dbyings rin po che'i mdzod).

- Precious Treasury of the Supreme Vehicle (theg pa'i mchog rin po che'i mdzod), vols. 1-2.

—. Precious Treasury of Words and Meanings (gsang ba bla na med pa 'od gsal rdo rje snying po'i gnas gsum gsal bar byed pa'i tshig don rin po che'i mdzod).

- Treasure Trove of Scriptural Transmission: Auto-Commentary of the Precious Treasury of the Expanse of Phenomena (chos dbyings rin po che'i mdzod kyi 'grel ba lung gi gter mdzod).

- White Lotus: Auto-Commentary of the Precious Wish-Fulfilling Treasury (theg pa chen po'i man ngag gi bstan bcos yid bzhin rin po che'i mdzod kyi 'grel pa padma dkar po).

Mipam ('ju mi pham rgya mtsho) (1846-1912). Beacon of Certainty (nges shes sgron me). Published in nges shes sgron me rtsa 'grel, pp. 1-54. Sichuan: Nationalities Press, 1997.

Collected Works (Dilgo Khyentsé's expanded redaction of sde dge edition). Kathmandu: Zhechen Monastery, 1987. 
- Commentary on the Wisdom Chapter of the Bodhicaryāvatāra (spyod 'jug sher 'grel ke ta ka). Sichuan: Nationalities Press, 1993.

- Difficult Points of Scriptures in General (dbu ma sogs gzhung spyi'i dka' gnad skor gyi gsung sgros sna tshogs phyogs gcig tu bsdus pa rin po che'i za ma tog). In Mipam, Collected Works, vol. 22, pp. 427-710.

. Intelligent Presence (gnyug sems 'od gsal ba'i don la dpyad pa rdzogs pa chen po gzhi lam 'gras bu'i shan 'byed blo gros snang ba). In Mipam, Collected Works, vol. 24, pp. 411-566.

- Lion's Roar: Exposition of Buddha-Nature (bde gshegs snying po'i stong thun chen mo seng ge'i nga ro). In Mipam, Collected Works, vol. 4 (pa), 563-607.

- Precious Vajra Garland (gnyug sems zur dpyad skor gyi gsung sgros thor bu rnams phyogs gcig tu bsdus pa rdo rje rin po che'i phreng ba). In Mipam, Collected Works, vol. 24, pp. 567-774.

—. Vajra Essence (gnyug sems 'od gsal ba'i don rgyal ba rig 'dzin brgyud pa'i lung bzhin brjod pa rdo rje snying po). In Mipam, Collected Works, vol. 24, pp. 353-410.

Phuntsho, Karma. Mipham's Dialectics and the Debates on Emptiness. London: RoutledgeCurzon, 2005.

Ricoeur, Paul. Interpretation Theory: Discourse and the Surplus of Meaning. Fort Worth: Texas Christian University Press, 1976.

Stearns, Cyrus. The Buddha from Dolpo: A Study of the Life and Thought of the Tibetan Master Sherab Gyaltsen. Albany: State University of New York Press, 1999. 